FOREIGN SERVICE AND THE AGE LIMIT.

To the Editor of THE. LANCET.

SIR,-Sir Alfred Keogh in his letter in your issue of March 13th (p. 572) makes a stipulation in paragraph 4 which must limit considerably the numbers at his disposal. $\mathrm{He}$ says that except in special cases men of over 40 years of age are not sent overseas: It seems that no distinction is made between two entirely different branches of the medical service in France. On the one hand, there is the work actually at the front, on the lines of communication, \&c.; and on the other, the work at the base hospitals. Perhaps for the former, where severe conditions are inevitable, an age limit of 40 is desirable, but for work at the base hospitals surely the services of men of experience, even though past the magic age, are not only welcome but indispensable. If a strict age limit: is made it will necessarily follow that the base hospitals will be staffed by young, inexperienced men, who, as compared with the civil hospital standard, are not surgeons at all, and yet they must decide questions and perform operations that require years of training. My own experience of this campaign in France assures me that the work of a surgeon at the base hospitals is not nearly as trying as the daily work of an operating surgeon at home, and could easily be done by men between 40 and 60 , an age when experience and matured judgment are at their best. If this suggestion of supplying older men.in the base hospitals could be adopted it would release a large number of younger men, who would, I know, jump at the chance of getting right to the front. I am, Sir, yours faithfully,

$$
\text { Harley-street, W., March 16th, } 1915 . \quad \text { H. W. CARSON. }
$$

\section{TREATMENT OF PAINFUL FROST-BITE.}

\section{To the Editor of THE LANCET.}

SIR,-The problem of how best to treat painful frost-bitten feet is one which doubtless has caused those in charge of military wards some anxiety.

The best remedy I have found to be the following :-

$$
\begin{aligned}
& \begin{array}{llllll}
\mathrm{R} & \text { Cocainæ } \ldots & \ldots & \ldots & \ldots & \text { gr. viii }
\end{array} \\
& \begin{array}{lllll}
\text { Ol. olivæ... } & \ldots & \ldots & \ldots & \zeta \text { iv. }
\end{array} \\
& \begin{array}{lllll}
\text { Liq. calcis } & \ldots & \ldots & \ldots & \zeta \mathrm{j} \text {. }
\end{array}
\end{aligned}
$$

Which simply means carron oil and cocaine. A small quantity is rubbed into the feet twice daily, special attention being given to the toes. The feet are massaged with it for a few minutes, afterwards being wrapped up in cotton-wool. It is an improvement to add 1 ounce of liquid paraffin to 4 ounces of carron oil. By this addition it prevents it oxidising so quickly and also from drying up so rapidly, and makes it less liable to rancidity. When the oil dries on the feet the following dusted on is an excellent powder : camphor, gr. $x \times x \nabla$.; zinc oxide and pulv, amyli, āà $\bar{\zeta}$ ss.

In all my recent cases in which there has been no ulceration it has been entirely successful; one advantage of this form of treatment is that the patient is able to sleep without any narcotic. When the acute stage passes off, the carron oil and cocaine are mixed with equal parts of carbolic oil, the percentage of which is increased as the pain decreases. Another very important consideration is the fact that the men can be the more quickly put on the convalescent list, thereby enabling them to get back sooner to the front.

\section{I am, Sir, yours faithfully,}

$$
\text { W. Charles Davis. }
$$

Darid Lowis Northern Hospital, Liverpolol, March 19th, 1915.
THE ANCESTRY OF EHRLICH.

\section{To the Editor of THE LANCET.}

SIR,-In The Lancet of Feb. 27th (p. 422) Sir W. Watson Cheyne is reported as saying, "Whatever may be thought of German Kultur in general Professor Ehrlich is the great pioneer in this work [chemotherapy]. ...... Ilook upon Professor Ehrlich as the greatest medical asset that the world possesses at the present time."

Now; I hope you will pardon me for pointing out that although possibly a naturalised German, Professor Ehrlich is stated by Dr. Garrison in his "History of Medicine," p: 95, as springing from a more ancient and more famous race-viz., the Hebrews-and Dr. Garrison also cites Cohnheim, Metchnikoff, Fränkel, Friedländer, and Neisser as belonging to the same ancestry. As Disraeli says in "Lothair," "Race is everything."

I am, Sir, yours faithfully,

Corris, Mèrioneth, Mâreh 19th, 1915: $\quad$ E. C. B. IBOTSON.

\section{A PLEA FOR CONSIDERATION. To the Editor of THE LANCET.}

SIR, - Your leading article with this title prompts me to write this letter, though I have not. the honour to belong to the profession by which you are almost exclusively addressed.

When the Insurance Act began to increase the emoluments of practice for some practi. tioners who joined the panels the cry that "the doctors" were getting overpaid was raised in many quarters by persons who equally would have been opposed to the raising of the salaries offered for those posts which are now so difficult to fill. To those who think that the medical profession has been, or is ever likely to be an overpaid calling, I may commend the careful consideration of the work now being. done by it on and in connexion with military service, the demand for more men to do that work, and the shortage of medical men in civil practice.

The proposition is that if the practice of medicine had offered better prospects of livelihood to the able young men who have had to choose callings for themselves during the past 30 years, there. would have been a proportionately larger supply to draw: upon in this great crisis of our national life. Grudgingly paid fees of the smallest possible dimensions, and salaries fixed at the lowest price to which competition can reduce them, have imposed upon many the necessity for arduous work by night and day before the bare neces. saries of life are earned, and have combined, under the inexorable law of supply and demand, to keep down the numbers of the medical profession in time of peace. In time of war it is too late to add to those numbers, because the training of the physician or surgeon is a matter of years not of months, and the numerical insufficiency now realised can only be made up for by strenuous devotion to duty, on the one hand, combined with reasonable patience and forbearance on the part of the public.

Neither devotion to duty nor patience will be relaxed at a time when our country with every resource at its command is fighting for the preservation of its national existence; but thoughtful citizens might well consider, when the war is over, whether a shortage of medical men is a safe national position. And if they find that it has its risks then will be the time to take the obvious measures of precaution. I am, Sir, yours faithfully,

March 22nd, 1915. A LAWYER. 